Revista de Indias, 1996, vol. LVI, núm. 208

\title{
ECONOMIC GROWTH AND THE CREATION OF THE VECINO HOMELAND IN NEW MEXICO, 1780-1820
}

POR

\section{ROSS FRANK}

Department of Ethnic Studies. University of California, San Diego

Much of the literature on the history of New Mexico assumes that the region is culturally distinctive, while missing the true historical source

AASF:BA: Archives of the Archdiocese of Santa Fe, Book of Baptisms, Santa Fe, New Mexico.

AASF:BU: Archives of the Archdiocese of Santa Fe, Book of Burials, Santa Fe, New Mexico.

ACD:DZ: Archivo de Catedral de Durango, Archivo Histórico, ramo de Diezmos, Durango, México.

ACD:VA: Archivo de Catedral de Durango, Archivo Histórico, ramo de Varios, Durango, México

AGN:HI: Archivo General de la Nación, ramo de Historias, México, D.F.

AGN:PI: Archivo General de la Nación, ramo de Provincias Internas, México, D.F.

CHI:RG: Registro de Propiedades, Archivos Históricos, Chihuahua, Chihuahua.

CPM:HA: Archivo Histórico, Palacio Municipal, Sección Hacienda, Chihuahua, Chihuahua.

CPM:NO: Archivo Histórico, Palacio Municipal, Sección Notaria, Chihuahua, Chihuahua.

DUR:PG: Archivo Histórico, Palacio Gobierno, Durango, Durango.

PBAN: Pinart Collection, Bancroft Library, University of California at Berkeley, Berkeley, California.

SANM I: Spanish Archives of New Mexico, series I, land grant records, New' Mexico State Records Center, Santa Fe, New Mexico.

SANM II: Spanish Archives of New Mexico, series II, provincial records New Mexico State Records Center, Santa Fe, New Mexico. 
of its uniqueness. This essay argues that nuevomexicanos emerged from late colonial New Mexico as a distinctive group of Vecinos largely due to a system of long-distance trade that expanded rapidly after 1786 until the outbreak of violence in Mexico in 1810. The dynamic vitality of Vecino culture, and many of its distinctive elements, proceeded directly from an era of economic activity in New Mexico at the end of the eighteenth century.

In an article written in 1970, geographer Richard Nostrand mapped what he termed the "Hispano Homeland", in the American Southwest. He divided the area populated by the Mexican-American population of about 140,000 reported in the 1900 United States census into "Stronghold», "Inland», and "Outland» regions based upon their percentage of Hispanic residents. Nostrand based his thesis on the historical assumption that the Spanish colonists of New Mexico represent a «culturally distinctive» group, at some point in the past becoming distinguishable from settlers elsewhere in northern New Spain (1). As J. M. Blaut and Antonio Ríos-Bustamante emphasize in their commentary on the Nostrand formulation, the identification of New Mexican Vecinos (2) as "a distinctive, Spanish-derived, non-Mexican subculture» forms an essential part of his definitions of «Hispanos», and his subsequent loca-

A much earlier version of paper was presented at the VIII Conference of Mexican - North American Historians, San Diego, October 1990 and at the Southwestern Social Science Association Conference (San Antonio, 1991). Funds for research in Mexico were provided by a Fulbright Doctoral Dissertation Research Grant (1987), and the Western History Association, (Rundell Graduate Student Award, 1987); those for writing due to the generous support of the Mabelle McLeod Lewis Memorial Fund (1989).

(1) Richard L. Nostrand, "The Hispano Homeland in 1900", Annals of the Association of American Geographers 70:3, 1980, p. 382.

(2) The Spanish word Vecino used here refers to the non-Indian settlers of New Mexico. The term, literally meaning "neighbor», took on a meaning that included a sense of belonging to the province in late colonial New Mexican documents. Settlers were commonly referred to by Franciscans or provincial officials as "Vecinos" in distinction to the "Indios", the inhabitants of the Pueblos, also signifying a type of neighbor. 
tion of them in a geographical «Homeland» (3). To its critics, the description of the Hispano Homeland as a geographical entity appears to its critics as a self-fulfilling result of the American occupation of northern Mexico a little over a half century before, unless Hispanic New Mexicans can be shown to have become culturally distinctive prior to 1846 .

In the "The Hispano Homeland in 1900" article, Nostrand supports his claim of New Mexican cultural difference by pointing to the early date of Spanish colonization of New Mexico, the archaic Spanish words that persist in the upper Río Grande valley to this day, and certain elements of New Mexican «Hispano» self-identification. In the series of exchanges which followed, Nostrand expanded on his contention that New Mexican settlers exhibited distinctive cultural traits by explaining that the settlers remained relatively insolated after their entrance on the scene, and hence retained «certain Iberian cultural forms», such as archaic words, names, folk plays, and folk songs, and developed traditions looking back to seventeenth century Spain and Mexico -New Mexican santos, and the Penitente Brotherhood-instead of contemporary New Spain (4). On this point, the participants in the "Hispano Homeland» debate have restricted themselves to whether a particular New Mexican trait distinguishes or does not distinguish New Mexicans from the inhabitants of other areas colonized by the Spanish (5).

As it stands, the discussion skirts the fundamental question of the significance of the cultural distinctiveness of Hispanic New Mexicans. As the Blaut-Ríos-Bustamante critique makes clear, any feature or group of traits within New Mexican society can appear similar to those found in some other Spanish co-

(3) J. M. Blaut and Antonio Rios-Bustamante, "Commentary on Nostrand's 'Homeland' Thesis", Annals of the Association of American Geographers 74:1, 1984, p. 157.

(4) Nostrand [1], p. 382; Richard L. Nostrand, "Comment in Reply", Annals of the Association of American Geographers 71, 1981, pp. 282-283; Richard L. Nostrand, "Commentary on Nostrand's 'Homeland' Thesis", Annals of the Association of American Geographers 74:1, 1984, pp. 164-167.

(5) See «Rejoinders», by Marc Simmons and Fray Angelico Chavez, Annals of the Association of American Geographers 74:1, 1984, pp. 169-171. 
lonial province, if not elsewhere in Northern New Spain (6). The problem remains that the participants in the Hispano Homeland discussion have substituted debate over the manifestations of culture for an examination of the underlying historical changes that resulted in the creation of a Vecino identity in New Mexico during the late colonial period. New Mexicans built a regional Hispanic culture and society at the end of the eighteenth century on the strength of fiscal and economic changes that effected all of New Spain, and reordered fundamentally the New Mexican economy within this wider context. The cultural manifestations of colonial, society mentioned by participants in the debate over Nostrand's "Hispano Homeland» thesis, such as the New Mexican santos, the Penitientes, their alabados, and the New Mexican folk plays such as Los Comanches, do not in themselves argue for New Mexican distinctiveness or regional cultural identification. Rather, each of the cultural trappings arose out of the province's experience of the last decades of Spanish colonial rule, stimulated and sustained by a period of rapid economic growth.

This article describes in summarized fashion the historical process of sub-regional cultural variation in New Mexico during the late colonial period. The thesis presented here addresses two questions suggested, but not directly confronted, by the participants in the original "Hispano Homeland» exchange and subsequent commentators. The first concerns the source of the manifestations of ethnicity and culture that became the focus of contention in the discussion of Nostrand's concept of the Hispano Homeland. If the trappings of Vecino culture in New Mexico derived principally from seventeenth and early eighteenth century Spain and Mexico, and survived in New Mexico as vestiges of this heritage somewhat modified by its colonial experience, then the issue hinges on whether or not these distinctions possess any cultural meaning in the face of the common late nineteenth, and twentieth century experience of the Spanish southwest as a part of the United States. The Nostrand position emphasizes the persistence of cultural distinctiveness among Hispanic sub-cultures that implies a basis for different

(6) See Blaut and Rios-Bustamante [3], p. 158.

R. I., 1996, n. 208 
interests and aspiration in the context of a dominant, overarching, Anglo culture. The opposing stance does not necessarily discount the regional variation of Hispanic culture, but dismisses the significance of these differences in the face of the subsequent historical subordination of Hispanic peoples in the United States (7).

On the other hand, if Vecinos created their own articulation of Hispanic culture in New Mexico at the end of the colonial period, as I argue here, both sides of the debate over distinctiveness among Hispanic New Mexicans have underestimated the relevance of the very forms cultural expression under consideration. In viewing the continuation of Spain cultural forms as a validation of distinctiveness, one ignores their significance as a marker for the economic and social changes that produced them as a form of cultural glue, giving shape and expression to Vecino society in late colonial New Mexico. This brings up the second question underlying the concept of the "Hispano Homeland»-how does Nostrand's formulation relate to the historical developments that took place on the periphery of late colonial New Spain?- and proposes an answer. The Hispano Homeland proposed and described by Nostrand represents the direct historical outgrowth of social and cultural changes set into motion in New Mexico by an economic boom at the end of the colonial period.

A number of general factors contributed to a sudden burst of activity in the late colonial New Mexican economy. Over the course of the eighteenth century, New Spain experienced accelerated population growth followed by geographic expansion, especially in the more sparsely populated northern provinces (8). The opening of major silver mines near Chihuahua, Parral, Guanajuato, and Durango in the 1760s and 1770s, along with the economic effect of the relaxation of trade regulations involved in the fiscal reforms of the Bourbon period, heightened commercial activity and investment throughout northern

(7) Along these lines see the historical interpretation of John R. CHAVEZ, The Lost Land: The Chicano Image of the Southw'est, Albuquerque, 1984.

(8) Michael M. Swann, Tierra Adentro, Boulder, 1982, pp. 37-170. 
New Spain, and particularly in Nueva Viscaya (9). The reorganization of the defense system of Presidios during the same period also contributed to the extension of regional centers and markets. Population growth around mining, presidial, and supply centers absorbed foodstuffs, raw materials, and commercial goods from surrounding regions which had previously provided materials for inter-regional trade. Furthermore, as local population and demand grew, regional markets had to draw supplies from more distant locations, especially during periods of dearth as occurred in a good portion of the 1780s (10).

These general factors combined with the particular circumstance of New Mexico to produce a spurt of growth and structural changes in the New Mexican economy in the latter half of the eighteenth century. Beginning in the 1750s, and intensifying during the 1770s, Apache, Ute, Navajo, and Comanche Indian hostilities checked the rate of growth of the province's population, limited access to agricultural land, and slowed commercial activity. Migration into New Mexico from other parts of New Spain had practically ceased by midcentury. Indian raids, especially by Comanche and Apache bands, encouraged closer cooperation between Pueblo Indians and Spanịsh settlers than at any time since the reestablishment of Spain power over New Mexico in the 1690s. Pressure from Indian raids threatened the continued existence of the province until the defeat of the Comanche leader Cuerno Verde in 1779, and the subsequent establishment of a Spanish-Comanche treaty alliance in 1785 (11).

In addition to the external phenomena discussed above,

(9) On the Bourbon Reform, and their effect on Mexican silver production during the second half of the eighteenth century, see David A. BRADING, Miners and Merchants in Bourbon Mexico, 1763-1810, Cambridge, 1971, pp. 33-168.

(10) Summarized here are number of studies of the internal and contextual economies of colonial haciendas, among them: David A. BRADING, Haciendas and Ranchos in the Mexican Bajio: León, 1700-1860, Cambridge, 1978, pp. 61-114; Brian R. HamnetT, Politics and Trade in Southern Mexico, 1750-1821, Cambridge, 1971, pp. 56-120; and especially Eric VAN Young, Hacienda and Market in Eighteenth Century Mexico, Berkeley, 1981, pp. 271-357.

(11) Oakah L. Jones, Jr., Pueblo Warriors and Spanish Conquest, Norman, 1966, pp. 131-169; Charles L. KenNer, A History of New Mexican-Plains Indian Relations, Norman, 1969, pp. 23-77; Alfred BARnABy ThOmas ed., The Plains Indians and New Mexico, 1751-1778, Albuquerque, 1940, pp. 21-55, and 111-211.

R. I., 1996, n. 208 
three internal elements coincided in the early 1780 s to define further the economic reorientation of New Mexico. A smallpox epidemic reached the province in 1780-81 and killed over twenty percent of a population of about 18,000 inhabitans (12). The baptism and burial records from the Santa Clara jurisdiction serve to illustrate the relative effect of the smallpox epidemic on the Indian and Vecino populations (13). After the initial

FIGURE 1A: SANTA CLARA BAPTISMS AND BURIALS, 1776-1786

Source: AASF, B-31, Bur-30

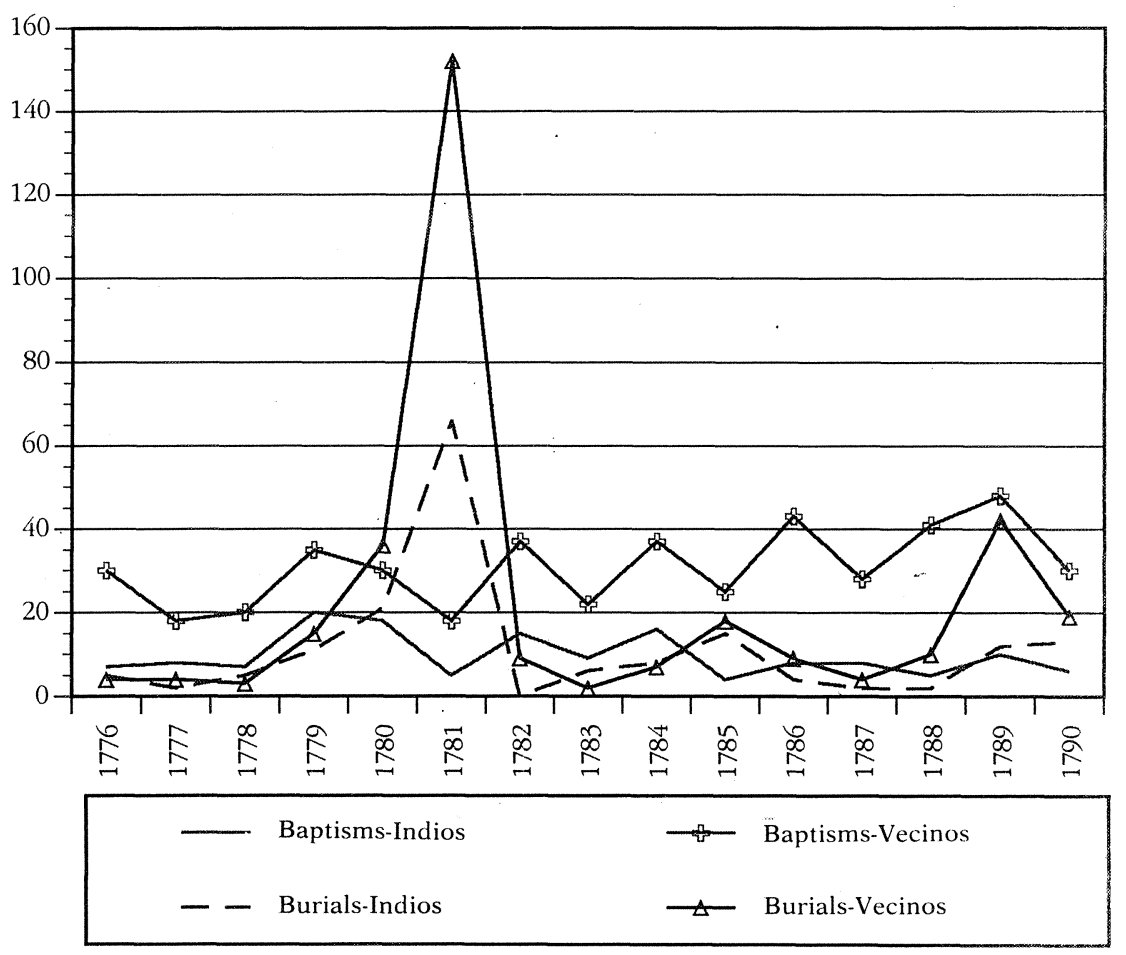

(12) A brief treatment of the epidemic is in Marc Simmons, "New Mexico's Smallpox Epidemic of 1780-81", New Mexico Historical Review, 41:4, 1966, pp. 319-326.

(13) Figures compiled from Archives of the Archdiocese of Santa Fe (AASF), Santa Fe, New Mexico, Bur-30 (Box 20), Santa Clara, 1726-1843, and B-31 (Box 44), Santa Clara. 
shock from an epidemic, a population normally responds by increasing its birth rate to make up for the loss. Figure 1a shows the rise in the birth rate beginning in 1782 for the Indian of Santa Clara Pueblo and the Vecino settlements of Chama, Cuchilla, Corrales de Piedra, La Vega, and Mesilla, as reflected in the recorded baptisms. The birth rate of both populations increased, but the rise in the Indian birth rate did not surmount its level of before the epidemic, except briefly during 1789 . In contrast, the Vecino birth rate climbed steadily throughout the period. Figure $1 \mathrm{~b}$ shows the change in the position of the two populations relative to the census figure give in 1776 by Fray

\section{FIGURE 1B: PERCENT POPULATION CHANGE FROM 1776, SANTA CLARA}

Source: AASF, B-31, Bur-30; Domínguez, Missions, 119

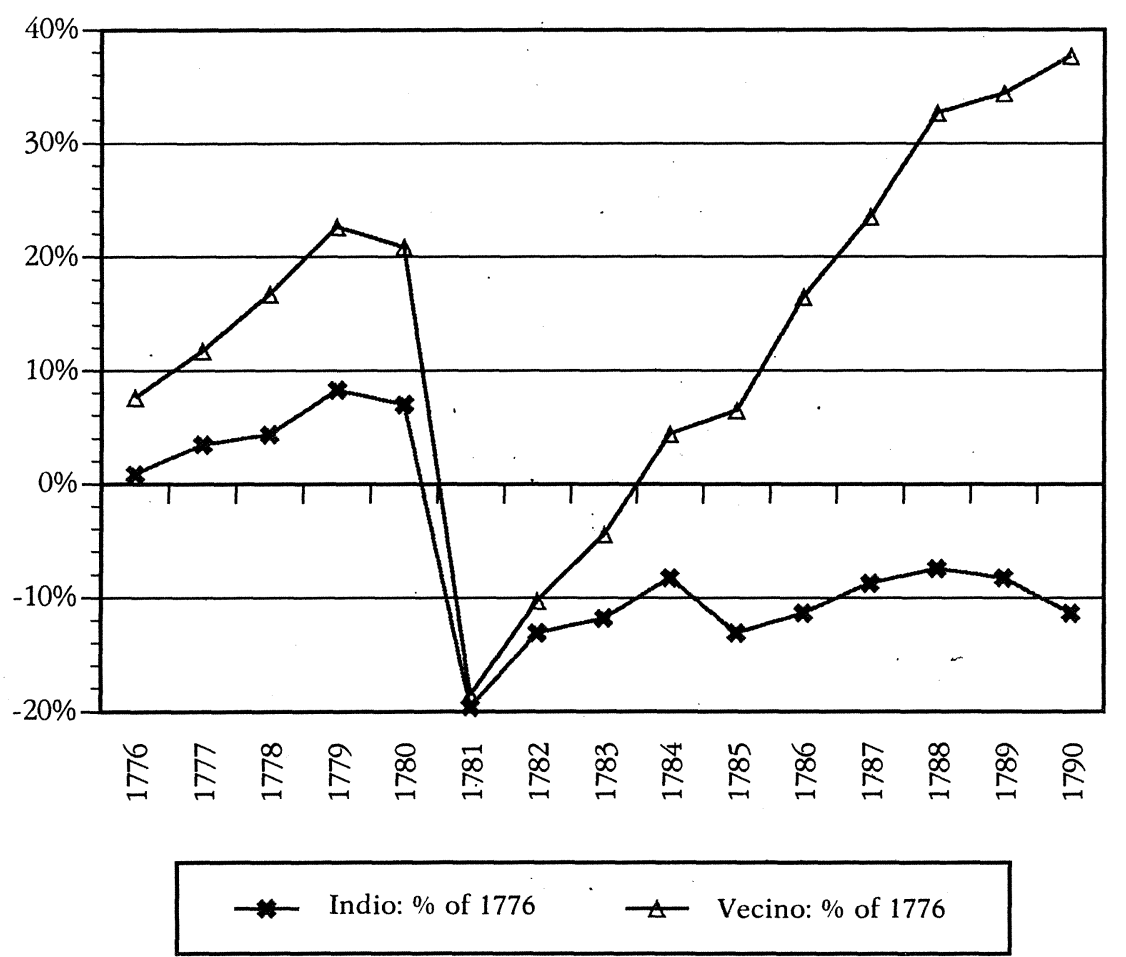

R. I., 1996, n.o 208 
Atanasio Domínguez (14). In percentage terms, the epidemic hit the Vecino populations somewhat harder than it did Santa Clara Indians, but after 1782 the Vecino bithrate rebounded rapidly, surpassing its 1776 level in 1787. In 1790, the population of the Vecino settlements stood almost thirty-eight percent higher than in 1776, the Pueblo population still showed a decline of over eleven percent.

More significant than the heavy mortality, recovery from the epidemic permanently changed the balance between the Pueblo Indian and Vecino population. The demographic impact of the epidemic had far less impact in the long run due to a rapid on the Vecino population, due to the subsequent rise in the birth rate. The effect of such a sudden change in the rate of mortality, on the other hand, served to concentrate the owneraship of land, livestock, and materials of production -resources which could then be quickly used to meet the growing demand for exports (15).

(14) Fray Atanasio Dominguez, The Missions of New Mexico, 1776, Ed. Eleanor B. Adams and Fray Angélico Chávez, Albuquerque, 1956, pp. 118-119.

(15) The reaction of the English economy to the bubonic plague of 1348 serves as an instructive example of the process at work. The sudden loss of somewhere between a quarter and a third of the population resulted in an immediate decrease in the price of agricultural goods, relative to manufactured goods coupled with mounting pressure for higher wages. See Harry A. MISKImIN, The Economy of Early Renaissance Europe, 1300-1460, Cambridge, 1975, pp. 25-32; and A. Elizabeth LEVETT and A. BALLARD, "The Black Death on the Estates of the See of Winchester" in Paul Vinogradoff, ed., Oxford Studies in Social and Legal Historv. Oxford, 1916, vol. V, especially chapter 2, p. 141; and M H. KeEN, England in the Later Middle Ages. London, 1973, pp. 169-174.

The records existing from fourteenth century England suggest a better climate for the farming peasant based upon the evidence of pressure on the great landowners to pay more to wage laborers, many of whom could not bargain freely. See M. W. BEAN, "The Black Death: The Crisis and its Social and Economic Consequences", in Daniel WILliams, ed. The Black Death: The Impact of the Fourteenth Century Plague. Binghamton, NY: Center for Medieval and Early Renaissance Studies, 1982, pp. 23, 33, especially pp. 30-31. Also sec the article of Leópold GERICOT in The Cambridge Economic History of Europe. Cambridge, 1966, 2nd ed., pp. 660-694.

In distinction to the villeins of late medieval England, who owed labor services and held their land from noble or ecclesiastical landlords, the eighteenth-century New Mexican farmers did not participate in any market that could have left traces of a change in the value of their services after 1781 
The second general factor concerned a special fund created in the 1780 by the Commandancia General as a part of the system of traities and alliances with the hostile Indian groups. Placed at the disposal of New Mexican governors to provide gifts for the allied parties, the officials purchased a significant portion of the goods given to the "naciones gentiles» from within the province, especially grain, sheep, and certain woven goods. Besides stimulating these branches of production and the manufacture of clothing from domestic and imported textiles, the extraordinary fund, as it was called, added a new source of specie to supplement the inadequate amounts coming into the province by way of official and presidial salaries (16).

Finally, the viceroy and the governors of the Provincias Internas pursued a conscious monetary strategy calculated to make available the capital and credit necessary to expand trade. During the 1780s, officials resurrected the system of libranzas, or libramientos, letters of credit payable at the Royal Treasury in Mexico City on money deposited in the provincial branches of the treasury, a procedure that had been suspended due to a recoinage of the peso in the early 1770s. The expansion of provincial Real Cajas, and the reestablishment of the libranzas were policies specifically aimed at keeping silver pesos in circulation in the northern provincial economies (17).

Aided by the various forces that converged on New Mexico in the mid-1780s, the provincial economy began a period of expansión fueled by a booming export trade to southern mar-

The underlying economic principle, however, remains the same: fewer workers on a quantity of land, which remained stable at least initially, increased the marginal productivity of the survivors. Evidence of the concentration of assets in the form of sheep held by New Mexican confraternities (cofradias) tends to confirm this hypothesis for New Mexico. See the audit of confraternity accounts in 1776, and again in 1791: Dominguez, Missions, 19, pp. 241-249, and Archivo Catedral de Durango [ACD], Varios [VA], 44:116, ff. 10R, 12R, 14R, 16R.

(16) Archivo General de la Nación (AGN), Mexico City, Provincias Internas (PI) tomo 67, expediente 1, 32R-111V, 112R-202V, 203R-389V, 390R-487V, 488R-595R; AGN:PI 201:15, 337R-341R; AGN:PI 204:15, 417R-419R; AGN: Historia (HI) $427: 8,1 \mathrm{R}-12 \mathrm{R}$

(17) See BRADING [9], pp. 100-104 for a description of bills of credit. The discussion over the reinstatement of the libranza system for Nueva Vizcaya (including New Mexico) appears in AGN:PI 45:2. 327R-334V, AGN:PI 46:1, 129R-129V, 131R-132V, 141R-143R, 152R-153V, 182R-183R, 201R-202R.

R. I., 1996, n. 208 
kets. The records of the New Mexican tithe rental allow an indirect measurement of the dimensions of the growth in production encouraged by increased trade (18). In theory, the Bishop of Durango held secular jurisdiction over the province of New Mexico from the time of the bishopric's foundation in 1621. When Bishop Antonio Crespo y Monroy attempted to carry out a visitation of the province in 1730, the Franciscan Custodian (Custos), Fray Andrés Varo, objected on the grounds that the Bishop had no authority over areas ministered to by the regular orders (19). Legal proceedings fallowed in which the Viceroy upheld the Bishop of Durango's right to nominal jurisdiction over the province. The Bishop's power extended. to the occasional visitation and appointment of ecclesiastical

(18) The Tithe records for New Mexico and Nueva Viscaya reside in the Archivo Catedral Historico, Durango, in 4 cajas and 13 paquetes of documents. Documents relevant to tithe assignment and collection also appear in the 55 cajas marked Varios (as of November 1988). The first New Mexican tithe was recorded on 30 IX 1734, for the year 1732 (ACD:Diezmo [DZ] caja 3, folio 7, foja 46R). A general summary of tithe collection in Mexico appears in Arij Ouweneel, and Catrien C. J. H. BiJleveld, "The Economic Cycle in Bourbon Central Mexico: A Critique of the Recaudación del diezmo líquido en pesos", Hispanic American Historical Review, 69:3, 1989, pp. 481-482. For a description of the historical development of a system of collecting tithes in one ecclesiastical jurisdiction, see Woodrow BORAH, "Tithe Collection in the Bishopric of Oaxaca, 1601-1867». Hispanic American Historical Review, 19:4, 1949, pp. 498-517. New Mexico follows the pattern of tithe collection in Oaxaca in the eighteenth century except that the jueces hacedores never switched to direct administration of tithe collection in the province. Marc Simmons describes tithe collection in New Mexico in Spanish Government, pp. 107-110, but with reference only to the sparse tithe information available in the Spanish Archives of New Mexico, State Records Center, Santa Fe.

(19) See the discussions of the controversy between the Franciscans and the Bishops of Durango over New Mexican jurisdiction in the first half of the eighteenth century in Dr. Pedro TAMARón Y Romeral, Bishop Tamarón's Visitation of New Mexico, 1760, Ed. Eleanor B. ADAMs, Publications in History. Albuquerque: Historical Society of New Mexico, 1954, pp. 1-19. Also published as Eleanor B. ADAMS, ed., «Bishop Tamarón's Visitation of New Mexico, 1760», New Mexico Historical Review, 28:2-4, 1953: pp. 81-115, 192-221, 291-315, and 29:1, 1954, pp. 41-47, see 28:2, pp. 81-99; and Hubert Howe BANCROFT, History of the Pacific State of North America: Arizona and New Mexico, 1530-1888, San Francisco: The History Company, 1888 (vol. XVII of Bancroft's Works), pp. 240-241. The first tithe records are found in ACD:DZ, 2:7, f. 46R, September 9, 1734 , for the year 1732 
judges and the right to the ecclesiastical tithe, ten percent of the province's annual production, which the Church collected in 1732 for the first time since the reconquest.

In practice, the Bishop of Durango depended upon merchants from the northern provinces and officials in New Mexico to administer the collection of the tithe owed to the Church. The ecclesiastical judges in charge of letting the tithe (Jueces Hacedores de la Junta de Diezmos) accepted bids for a contract yielding the right to collect from the citizenry. Church officials in Durango auctioned (remate) the right to collect the tithes in most jurisdictions of Nueva Vizcaya for terms of two five years, in return for a flat, annual rental fee. In New Mexico this fee represented somewhere between one-third to one-half of the true value of the total goods which the lessee of the tithe could in theory collect. Such a high discount reflected the difficulty of finding a market in which to dispose of agricultural goods in a province three month's journey from Chihuahua, and often beset by Comanche and Apache raiding parties (20). Figure 2 graphically represents the annual peso value of the New Mexican tithe rental from 1732 to 1819 (21).

Since Spanish officials based the tithe on a fixed percentage of each year's production, changes in the rate at which renters compensated the Church for the right to collect it should bear a relationship to increases or decreases in the actual production of the assessed goods. However, despite the significant increase in income the bishopric of Durango received for the tithe over the eighty-seven years shown in Figure 2, the value of the rental itself does not necessarily denote an increase in economic production. One must gauge the effect of a number of phenomena that would tend to distort or counteract any re-

(20) See Fray Juan Augustín DE Morfí, Account of Disorders in New Mexico, 1778, Ed. Marc Simmons, Isleta Pueblo, N.M., 1977, p. 22.

(21) Sources for Figure 2: ACD:DZ, caja 3, foja 13 (3:13), folios $16 \mathrm{R}=, 67 \mathrm{R}$ (1750-1751); 2:12, 24R (1752); 3:12, 42R (1753); 3:14 18R, 42R (1754-1755); 3:15 $18 \mathrm{R}, 82 \mathrm{R}$ (1756-1757); 3:16 23R, 65R, 97R, 142R (1758-1761); 3:17, 24R, 56R (1762-1763); 3:18, 25R, 61R (1764-1765); 4:21, 23R, 41R (1770-1771); 4:23, f. 28R, 63R, 100R, 139R (bis), 166R, 188R (1773-1779). From 1785, New Mexico was included in the same documents as diezmos from Nueva Viscaya (see note 27 below) and in ACD:VA cajas 30-57 (1781-1801).

R. I., 1996, n.o 208 
FIGURE 2: NEW MEXICO TITHE RENTALS, 1732-1819

(logarithmic scale and peso value)

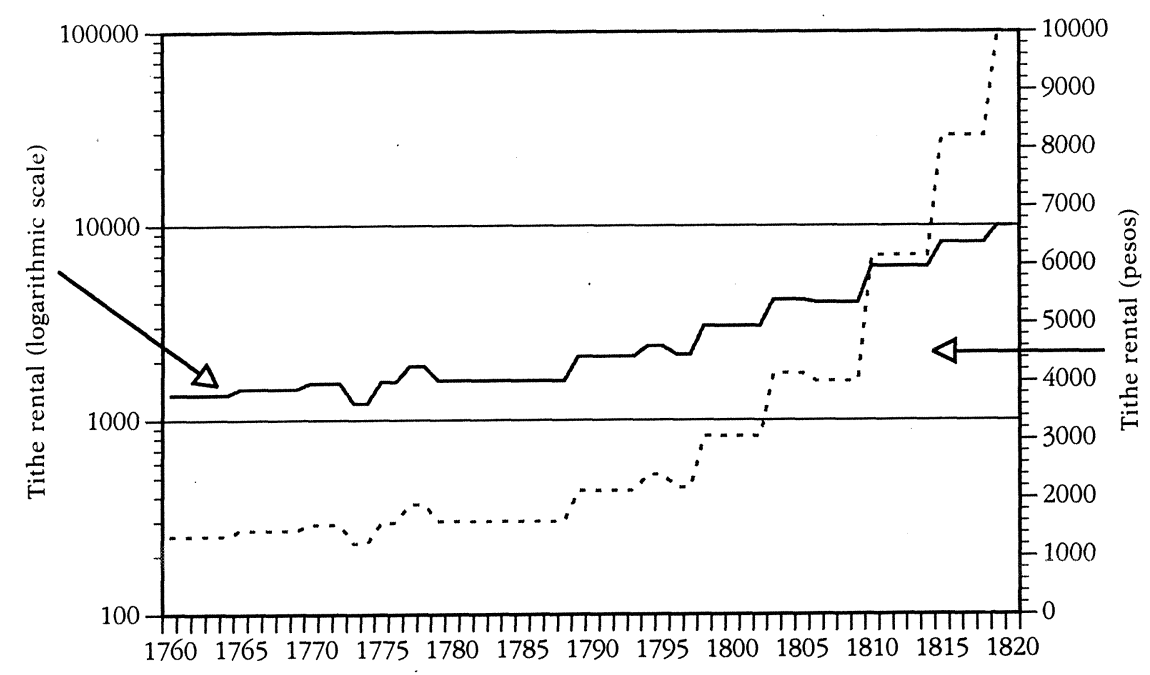

lationship that the series of tithe rentals might otherwise indicate. Price inflation during the period of increase could account for a rise in the money value of the successful bid for the tithe, instead of the higher rental indicating an expectation of collecting more produce in tithe. In addition, one must evaluate any attempt to collect revenue from individuals, whether in cash or in kind, in the context of the Bourbon attempts to centralize and enhance authority and maximize fiscal control over the northern provinces during the late colonial period. Rising rental values could also represent no more than an increasingly effective Bourbon state aiding the Bishopric of Durango in its collection of the New Mexican tithe.

The mechanics surrounding both the letting and the collection of the tithe could also introduce variables into the process that could alter the relationship between the rental value and changes in productivity. We will look in turn at each of these issues which bear upon the interpretation of the economic significance of the tithe rental data: the effect of price inflation on the real value of the tithe rental; and the authenticity of the relationship between the tithe rental series and the New Mexican 
economy given the tithe farming process, and the potential for change in the administration of tithe collection.

Beginning with the work of Enrique Florescano on maize prices, a number of studies suggest that late colonial Mexico suffered a period of severe price inflation (22). In central Mexico inflation posed an especially serious problem, particularly after 1779, almost at the same point that the tithe rentals for New Mexico begin to increase at an accelerating pace. The issue presents difficulties for the use of the monetary value of the tithe rental as an indication of an increase in per capita production, since the rise in the peso value of the tithe could reflect simply the loss of purchasing power of the peso (23).

Ideally, one would compile a series of prices of each of the component products collected for the tithe. From these once could construct a composite series reflecting the peso value of the mix of goods received from the collection of the tithe. This price series could then serve to deflate the tithe rental values, correcting for the influence of price inflation (24). If the data used to deflate the tithe rental merits high confidence as to its reliability, and similarly consistent population data exists, a measure of growth or decline of economic productivity per capita could be obtained.

At present, no single, consistent source gives the annual price of the major items that made up the tithe collected in New Mexico. However, a variety of sources yield prices for various goods at scattered points between 1760 and 1820 (25). These prices do not represent enough data to create a complete price

(22) Enrique Florescano, Precios del maiz y crisis agricolas en México (1708-1810). México: El Colegio de México, 1969, revised México: Ediciones Era, 1986. Also see OUWENEEL and BIJLEVELD [18], pp. 479-481, for brief review of the literature on price inflation in late colonial Mexico.

(23) See OuweneEl and BiJleveld [18] for an attempt to show that late colonial tithe rental increases reflect primarily the effects of inflation.

(24) For an excellent study demonstrating the proper deflating of tithe rental records to elucidate agricultural production, see Enrique TANDETER and Nathan WACHTEL; "Prices and Agricultural Production: Potosí and Charcas in the Eighteenth Century", in Lyman L. JOHnSON, and Enrique TANDETER, eds., Essays on the Price History of Eighteenth-Century Latin America, Albuquerque: University of New Mexico Press, 1990, pp. 201-276.

(25) For the sources of the prices for 1760-1820, see FRAnK, Settler to Citizen, Sources for Table 7, pp. 450-453.

R. I., 1996, n. 208 
series for each product collected in the tithe, but yield sufficient information to allow for a price index based upon key tithe goods that suggests the effect of inflation upon the late colonial New Mexican economy. Even adjusted for inflation in this manner, the tithe rentals show a significant increase in real value over the last sixty years of Spanish colonial rule.

Table 1 shows the data used to deflate the tithe rental series for New Mexico during the 1760-1820 period. Column 2 shows the rental paid each year to the Bishopric of Durango for the right to collect the tithe for the current year. Column 3 shows the tithe rental series normalized based on the decade 1774-1783. This decade straddles the last years of the fighting against the nomadic Indians, the first years of peace, and the smallpox epidemic. As we will see shortly, this period also represents the point when the Vecino population reached and permanently surpassed that of the Pueblos.

A fortuitous note on an accounting of the goods collected in New Mexico for the tithe during the biennial 1798-1799 shows the peso value that each product brought when sold by the lessee of the tithe (26). Sheep, maize, and wheat constitu-

(26) Extract general en que manifiestan las cantidades (de todo) que se han colectado de Diezmos en la provincia de Nuevo México por los años de 1798 y 1799... ACD:DZ Paquete 1807. The total value (in pesos) received for each product appears in a note on the lower, right-hand corner of the document:

REGULACIÓN PRUDENTE:

\begin{tabular}{|l|c|c|r|}
\hline \multicolumn{1}{|c|}{ PRODUCT } & PRICE & AMOUNT & TOTAL \\
\hline Trigo (Wheat) & 12 reales/fanega & 3202 fanegas & $4800 / 0$ \\
Maí (Corn) & 4 reales/fanega & 4257 fanegas & $2078 / 4$ \\
Frijol (Beans) & 6 reales/fanega & 169 fanegas & $126 / 6$ \\
Chile & 6 reales/fanegas & 224 fanegas & $199 / 4$ \\
Verza sopa cebollas & 5 reales/? & 4528 cebollas \& & $30 / 0$ \\
(vetch \& onions) & 183 f. legumbres & $118 / 2$ \\
Punche (tobacco variety) & 1 real/manojo & 956 manojos & $306 / 0$ \\
Becerros (calves) & 1 peso/cabeza & 285 cabezas & $2312 / 0$ \\
Borregos (lambs) & 4 reales/cabeza & 5219 cabezas & $9971 / 0$ \\
\hline & TOTAL: & (in pesos/reales) & 9 \\
& &
\end{tabular}

NOTE: The amounts given are from a separate schedule (except for frijol) and do not always tally with the unit price and total given in the notation mentioned above. 
TABLE: 1: NEW MEXICO PRICE INDEX OF SHEEP, MAIZ, AND WHEAT, 1760-1820

\begin{tabular}{|c|c|c|c|c|c|c|c|c|}
\hline & $\begin{array}{c}\text { NM } \\
\text { Tithe } \\
\text { Rental }\end{array}$ & $\begin{array}{c}\text { NM } \\
\text { Rental } \\
\text { Index }\end{array}$ & Sheep & Maiz & Wheat & Average & $\begin{array}{l}\text { Price } \\
\text { Index }\end{array}$ & $\begin{array}{c}\text { Deflated } \\
\text { Rental } \\
\text { Index }\end{array}$ \\
\hline 1760 & 1350 & 83.49 & 4 & 8 & 8 & 6.67 & 62.50 & 133.58 \\
\hline 1761 & 1350 & 83.49 & & & & & & \\
\hline 1762 & 1350 & 83.49 & 4 & & & & & \\
\hline 1763 & 1350 & 83.49 & & & & & & \\
\hline 1764 & 1350 & 83.49 & & & & & & \\
\hline 1765 & 1450 & 89.67 & & & & & & \\
\hline 1766 & 1450 & 89.67 & & & & & & \\
\hline 1767 & 1450 & 89.67 & & & & & & \\
\hline 1768 & 1450 & 89.67 & & & & & & \\
\hline 1769 & 1450 & 89.67 & & & & & & \\
\hline 1770 & 1550 & 95.86 & & & & & & \\
\hline 1771 & 1550 & 95.86 & & & & & & \\
\hline 1772 & 1550 & 95.86 & & & & & & \\
\hline 1773 & 1220 & 75.45 & & & & & & \\
\hline 1774 & 1220 & 75.45 & & & & & & \\
\hline 1775 & 1580 & 97.71 & & & & & & \\
\hline 1776 & 1580 & 97.71 & 4 & 8 & 8 & 6.67 & 62.50 & 156.34 \\
\hline 1777 & 1895 & 117,19 & & & & & & \\
\hline 1778 & 1895 & 117.19 & 8 & 12 & 12 & 10.67 & 100.00 & 117.19 \\
\hline
\end{tabular}

R. I., 1996, n.o 208 
TABLE: 1: NEW MEXICO PRICE INḊEX OF SHEEP, MAIZ, AND WHEAT, 1760-1820 (Cont.)

\begin{tabular}{|c|c|c|c|c|c|c|c|c|}
\hline & $\begin{array}{c}\text { NM } \\
\text { Tithe } \\
\text { Rental }\end{array}$ & $\begin{array}{c}\text { NM } \\
\text { Rental } \\
\text { Index }\end{array}$ & Sheep & Maiz & Wheat & Average & $\begin{array}{l}\text { Price } \\
\text { Index }\end{array}$ & $\begin{array}{c}\text { Deflated } \\
\text { Rental } \\
\text { Index }\end{array}$ \\
\hline 1779 & 1600 & 98.95 & & & & & & \\
\hline 1780 & 1600 & 98.95 & & 16 & & & & \\
\hline 1781 & 1600 & 98.95 & & & & & & \\
\hline 1782 & 1600 & 98.95 & & & & & & \\
\hline 1783 & 1600 & 98.95 & & & & & & \\
\hline 1784 & 1600 & 98.95 & 14 & & & & & \\
\hline 1785 & 1600 & 98.95 & & & & & & \\
\hline 1786 & 1600 & 98.95 & 8 & 16 & 14 & 12.67 & 118.75 & 83.33 \\
\hline 1787 & 1600 & 98.95 & 10 & 15 & 16 & 13.67 & 128.13 & 77.23 \\
\hline 1788 & 1600 & 98.95 & 8 & 16 & 16 & 13.33 & 125.00 & 79.16 \\
\hline 1789 & 2125 & 131.42 & 12 & 14 & 16 & 14.00 & 131.25 & 100.13 \\
\hline 1790 & 2125 & 131.42 & 12 & 16 & 16 & 14.67 & 137.50 & 95.58 \\
\hline 1791 & 2125 & 131.42 & 12 & 18 & 16 & 15.33 & 143.75 & 91.42 \\
\hline 1792 & 2125 & 131.42 & & & & & & \\
\hline 1793 & 2125 & 131.42 & 10 & 16 & 16 & 14.00 & 131.25 & 100.13 \\
\hline 1794 & 2401 & 148.48 & 7 & 10 & 16 & 11.00 & 103.13 & 143.99 \\
\hline 1795 & 2401 & 148.48 & & & & & & \\
\hline 1796 & 2180 & 134.82 & 8 & & & & & \\
\hline 1797 & 2180 & 134.82 & 8 & 10 & & & & \\
\hline
\end{tabular}

R. I., 1996, n. 208 
TABLE: 1: NEW MEXICO PRICE INDEX OF SHEEP, MAIZ, AND WHEAT, 1760-1820 (Cont.)

\begin{tabular}{|c|c|c|c|c|c|c|c|c|}
\hline & $\begin{array}{c}\text { NM } \\
\text { Tithe } \\
\text { Rental }\end{array}$ & $\begin{array}{c}\text { NM } \\
\text { Rental } \\
\text { Index }\end{array}$ & Sheep & Maiz & Wheat & Average & $\begin{array}{l}\text { Price } \\
\text { Index }\end{array}$ & $\begin{array}{c}\text { Deflated } \\
\text { Rental } \\
\text { Index }\end{array}$ \\
\hline 1798 & 3054 & 188.87 & 8 & 4 & 12 & 8.00 & 75.00 & 251.82 \\
\hline 17991 & 3054 & 188.87 & 8 & 4 & 12 & 8.00 & 75.00 & 251.82 \\
\hline 1800 & 3054 & 188.87 & & & & & & \\
\hline 1801 & 3054 & 188.87 & & & & & & \\
\hline 1802 & 3054 & 188.87 & & & & & & \\
\hline 1803 & 4135 & 255.72 & & & & & & \\
\hline 1804 & 4135 & 255.72 & & & & & & \\
\hline 1805 & 4135 & 255.72 & 8 & 8 & 12 & 9.33 & 87.50 & 292.25 \\
\hline 1806 & 4000 & 247.37 & 8 & 12 & & 6.67 & & \\
\hline 1807 & 4000 & 247.37 & 8 & & 16 & 8.00 & & \\
\hline 1808 & 4000 & 247.37 & 9 & & & & & \\
\hline 1809 & 4000 & 247.37 & 9 & & & & & \\
\hline 1810 & 6153 & 380.52 & 10 & 12 & & & & \\
\hline 1811 & 6153 & 380.52 & 9 & 12 & & & & \\
\hline 1812 & 6153 & 380.52 & 10 & 11 & & & & \\
\hline 1813 & 6153 & 380.52 & 9 & & & & & \\
\hline 1814 & 6153 & 380.52 & 9 & 23 & 23 & 18.33 & & \\
\hline 1815 & 8215 & 508.04 & 9 & 23 & 23 & 18.33 & 171.88 & 295.59 \\
\hline 1816 & 8215 & 508.04 & 8 & 18 & 24 & 16.67 & 156.25 & 325.15 \\
\hline
\end{tabular}

R. I., 1996, n. ${ }^{\circ} 208$ 
TABLE: 1: NEW MEXICO PRICE INDEX OF SHEEP, MAIZ, AND WHEAT, 1760-1820 (Cont.)

\begin{tabular}{|c|c|c|c|c|c|c|c|c|}
\hline & $\begin{array}{c}\text { NM } \\
\text { Tithe } \\
\text { Rental }\end{array}$ & $\begin{array}{c}\text { NM } \\
\text { Rental } \\
\text { Index }\end{array}$ & Sheep & Maiz & Wheat & Average & $\begin{array}{c}\text { Price } \\
\text { Index }\end{array}$ & $\begin{array}{c}\text { Deflated } \\
\text { Rental } \\
\text { Index }\end{array}$ \\
\hline 1817 & 8215 & 508.04 & 7 & 20 & 20 & 15.67 & 146.88 & 345.90 \\
\hline 1818 & 8215 & 508.04 & 7.5 & & & & & \\
\hline 1819 & 10000 & 618.43 & 8 & & & & & \\
\hline 1820 & 10000 & 618.43 & 9 & 24 & 24 & 19.00 & 178.13 & 347.19 \\
\hline
\end{tabular}

ted by far the most valuable products collected by the tithe. These three commodities together composed over ninety-two percent of the value of the New Mexican tithe material collected in 1798 and 1799. The other years where information about the volume of products collected exists, 1796-1797, $1800-1801,1803,1806$, and 1811, show a similar pattern. Sheep, maize, and wheat account between 95.6 percent of the total estimated value of the tithe products collected in 1796-97, down to 77.9 percent in 1811, with an average of almost eighty-eight percent. Columns 4, 5 and 6 show the prices collected where available for sheep, maize, and wheat, respectively. At this time only eighteen of the years during the sixty year period have a complete set of prices.

Finding data on the volume of sheep, maiz, and wheat collected for the tithe in order to weight the prices of the three commodities poses a more complicated problem. A detailed accounting of the volume of the goods collected for the tithe in New Mexico survive for the biennials 1796-97, 1798-1799, 1800-01, and for the years 1803 and 1806. Using this information and prices of the individual products, one may calculate the percentage of the total value of the tithe represented by each type of good collected. The results show no pattern that would suggest a standard to use for adjusting the price information given in columns 4,5 and 6 . None of the estimated weighted values for the three commodities strayed far from 
the average of their prices with the exception of the calculation for the 1798-1799 list of products collected using the annotated price schedule mentioned above. If the weighted values for 1798-1799, calculated in this manner, are substituted for the average price of the theree products in the composition of the price index, they make a negligible difference in the final result. In the absence of convincing data to do otherwiese, I used the average price of the basket of the three key tithe products to make up the composite price for each year where the three prices exist, as shown in Table 1, column 7.

Table 1, column 8 lists the composite prices in column 7 normalized using 1778 as the base. The year 1778 falls roughly in the middle of the decade used to normalized the tithe rental in column 3 (1774-1783), and we have record of the price for all three commodities during that year. Column 8 suggests that New Mexico felt the effects of two broad waves of price inflation during the last decades of colonial rule. The first extended from the mid-1780s into the mid-1790s. After a period of deflation in the mid to late 1790s, the inflationary period second began between 1807 and 1814 and lasted until sometime after Mexican Independence. Column 9 gives the real value of the tithe rental as a percentage of the value of the base year of 1778 , obtained by dividing the tithe rental index (column 3) by the price index (column 8).

As the deflated value of the tithe rental shown in Table 1, column 9 indicates, even when adjusted for inflation the money value of New Mexican produce taken in tithe grew significantly after 1786. At the end of the colonial period, New Mexicans contributed goods worth about two and one-half times the value of their those collected at the time of the alliance with the Comanche thirty-five years earlier. The tithe information indicates that collection in New Mexico also increased in relation to the larger economic region. Between 1774 and 1819 the New Mexican tithe yield increased almost threefold as a percentage of the total tithe rental value for the eight largest jurisdictions of Nueva Vizcaya (27). We will return to these figures to explore their significance for economic growth of the province.

(27) The following percentages are based on Frank [25], Table 5, pp. 439-446. The seven jurisdictions are: Chihuahua, Durango, Nombre de Díos,

R. I., 1996, n. 208 
We now turn to consideration of the variables introduced by the mechanics of letting the tithe contracts and collecting produce to satisfy the tithe. The records of the committee responsible for tithe administration (Junta de Diezmos) at the cathedral in Durango indicate that beginning in 1785, the contracts awarded for the right to collect the tithe in New Mexico elicited increased competition. The committee had not altered the standard process of accepting written bids (pregones) during the year that the current contract ended for the next period. Instead, the prospective leaseholders saw the opportunity to turn greater profits as the New Mexican economy revived, and the Church officials in charge of the system attempted to maximize the income gained from letting the tithe contract. The result of heightened competition tied the value of the tithe rental more closely to productivity within the province.

Since 1744 , when the tithe rental brought 1,550 pesos, successful bids ranged for the most part between that figure and 1,750 pesos. Exceptions directly reflected relations with the hostile Indian groups, such as the low rentals in the biennial contracts of 1758-59 and 1773-74. As we have seen, Governor Cachupín's offer of 1,750 pesos for the rental in 1763-65 stemmed from his efforts at making peace with the Comanche. In similar fashion, the sudden interest in the tithe contract for 1785-86 drew from knowledge of concerted moves towards peace between the Comanche and Governor Anza (28). In addition, the drought which struck Nueva Vizcaya in the mid-1780s had

Parras, Real de Oro (Indé), Río Grande (includes the vento after 1794), San Bartholomé, San Juan del Río.

\begin{tabular}{|l|l|l|l|l|l|l|l|l|l|}
\hline 1774 & 1780 & 1785 & 1790 & 1795 & 1800 & 1805 & 1810 & 1815 & 1819 \\
\hline 1.69 & 2.33 & 2.21 & 2.61 & 2.37 & 2.80 & 3.53 & 2.88 & 4.33 & 4.92 \\
\hline
\end{tabular}

The increase in the New Mexican percentage of the total tithe appears more impressive when one takes into account a significant rise in the population of Nueva Viscaya beginning during the late 1780 s. See Michael M. SwANN, Tierra Adentro, Boulder: Westview Press, 1982, p. 98 (figure 3.3), and pp. 139-155.

(28) THOMAs, Frontiers, pp. 71-73. 
begun to push grain prices up in Chihuahua by early 1783, and they rose in successive stages until they reached their peak in May of 1787 (29). Bishop Esteván Lorenzo de Tristan described the dire situation of Nueva Vizcaya in February of 1787:

The three gravest calamities of famine, epidemic disease, and war that the provinces of Our Bishopric have suffered for the past 3 years, gave just cause to Our Venerable Dean and Cabildo when the See was vacant to dispense with the use of meat and milk cows during the sacred period of Lent, because of the general lack of food necessary for human life that has been felt in all of the province (30).

Prices fell dramatically during the second half of 1787, reflecting the end of the drought and a good year's harvest.

Drought and dearth did not affect New Mexico as it did Nueva Vizcaya in 1783-87, or the new Indian allies of New Mexico in 1789-91. New demand brought higher prices for New Mexican goods that, for the first time in decades, could proceed down the Chihuahua Trail in relative security. The price of sheep moved from its traditional price of one peso, to twelve reales (one and a half pesos) in 1789, were it remained at least until 1791 (see Table 1). The price of punche (a native plant used as a tobacco substitute) rose from four reales in 1786, five or six on 1787, to eight in 1789 . By 1786, grain prices had already risen to new levels. The price of commodities such as maiz, wheat, and beans responded to changes in the market within the province, since the transport of these bulky items cost too much to make their sale in Chihuahua economically viable (31).

(29) The leading monthly prices for maiz and wheat flour sold by the public granary in Chihuahua (Real Alhondiga) between 1782 an 1791 illustrate the effect of the drought on the supply of grain. The prices were collected from documents covering 1782-1791 in the Archivo Historico of Palacio Municipal, Chihuahua, Chihuahua: CPM:HA, 47:19, Libro borrador de salidas diarias de maíz y harina... Real Alhondiga de Chihuahua. Prices for October, 1784 and November, 1785 from Francisco del Valle to Jueces Hacedores de Durango, 1 XI 1785. DCA:VA, caja 32, folio 86, 1R, V (two-page letter). See also SwANN [27], pp. 128, and 131-132.

(30) Memorial of Bishop of Durango, Esteván Lorenzo de Tristan, Durango 12 II 1787. DCA:VA, caja 32 folio 86, $1 \mathrm{R}$ (thirty-four pages).

(31) For example, in 1812 the carrying charge of a fanega of maiz or wheat

R. I., 1996, n. 208 
In contrast, in difficult times El Paso del Río del Norte could supply grain to the Presidios of San Elizario, Carrizal; del Norte, and even Chihuahua, in addition to its normal export of wine, aguardiente, and dried fruit (32).

The effect of both of dearth outside of the province and moves towards peace within, spurred interest in the contract for New Mexican tithes in 1785 when it became due for re negotiation. Since Don Clemente Gutiérrez had won the contract covering 1781-84 at a price of 1,700 pesos a year, the bidding in 1785 represented the first time enterprising settlers had a chance to compete for the tithe contract under new economic conditions. On April 5, 1785, Don Diego Antonio Baca, who had administered the tithe contract in $1777-78$, bid 1,700 pesos on behalf of Don José Mariano de la Peña, "a resident of Santa Fe», and Don Clemente Gutiérrez, described as «a merchant of this land [New Mexico]» (33). Two days later, Don José Mariano de la Peña, now with power of attorney from the soldiers of the Presidio, bid the same amount. On April 9, the captain of the militia and Alcalde Mayor of Santa Fe, Don Antonio José Ortiz, bid 1,800 pesos per year for the contract and five hundred more to seal the bid. This development led to Antonio Baca withdrawing his bid, on new instructions from Gutiérrez on the thirteenth, leaving Ortiz the winner. On April 14, Ortiz agreed to pay 2,120 pesos for two years, and the Durango officials overseeing the tithe rental awarded the 1785-86 contract for

to Santa Fe from Taos, Río Arriba, or San Miguel de Bado cost four, two, and three reales per fanega, respectively. At the time a fanega of maiz brought eleven reales, a carrying charge of 36, 18, or 27 percent! Entry for 31 XII 1812, Accounts of the Presidio of Santa Fe, Spanish Archives of New Mexico (SANM II), Santa Fe, Twitchell (TW), n.o 1818a [Twitchell, number refers to listing in Ralph E. Twitchell, The Spanish Archives of New Mexico, Cedar Rapids, Iowa, 1914], microfilm edition: roll 15:522.

(32) Report on tithe collection in Chihuahua, El Paso del Río del Norte, Nuevo México, and the frontier presidios. Juan Ysidro Campor to the Señores Jueces Hacedores, Dr. Don José Martín Flores and Don Julián Valero de Vicente. [Durango?], 6 IX 1797, ACD:VA, 55:145, 12V-13R.

(33) 'The 1785 pregones are in ACD:VA, 32:86, 7 hojas. Ruíz paid for 1785 in Chihuahua, on 31 XII 1785. ACD:VA, 32:86, 1R, V, 1 hoja. The records of the New Mexican tithes for 1785 are listed as ACD:VA, 33:87, but could not be located in November, 1988 
New Mexico to this «merchant of the same Province». At the end of the year, Ortiz's guarantor, Don Manuel Ruíz, paid the first installment of 2,125 [sic] pesos. The final payment Ruíz presented on March of 1787 on behalf of Ortiz in the form of two libranzas (34).

Vigorous competition over the New Mexico tithe contract of 1802 caused another large jump in the rental offered to the Church in Durango. Don Miguel Ortiz, a Vecino from New Mexico, offered 3,300 peso's each year for two biennial contracts (1802-1805) (35). This amount represented only slightly more than the 3,054 pesos per year paid by Governor Concha for the previous contract. Juan Joseph Zambrano, a member of the wealthy merchant and mining family in Durango, represented Don Manuel de Asorez y Bermuda to the tithe judges with a bid for 14,000 pesos for the same four year period resquested by Ortiz. Another merchant, Don Mariano Garvino extended the same offer for only 1802-1803 biennial, giving the tithe officials added flexibility in choosing the length of the next contract. A third bid came from Don Pedro Moreno, who raised the price to 14,000 pesos for the four years, 3,625 pesos per year. Finally, Ortiz raised his bid to 16,540 pesos $(4,135$ per year) through his legal agent, Don Antonio Ramón de Landa, and received the contract.

The proceding analysis of the New Mexican tithe rental has shown that despite the inflationary pressures felt within the province during the end of the colonial period, the value of the tithe contract outpaced the rise in the price of the major tithe goods. Further, the investigation of the mechanics of auctioning the contract show a direct, if not always constant, relationship between the economic condition of the province and the rental value of the tithe. The overriding concern of all parties to maxi-

(34) Libranzas for 2000 pesos in favor of Ruíz; and 125 pesos drawn by Don Manuel Francisco de la Brena, against don Juan de Guardamino of Mexico City, to be collected from Don Juan Felipe Laurnaga, Chihuahua, 29 II 1787. ACD:VA, 34-90, 1 hoja. In 1794 Laurnaga is listed as a creditor in Veracruz, see Pedro PÉrez HERRERo, Plata y libranzas. La articulación comercial del México borbónico; México: El Colegio de México, 1988, p. 241.

(35) The 1802 pregones are in ACD:DZ, paquete 1802, 12 hojas and 2 inserted letters.

R. I., 1996, n.o 208 
mize their financial advantage ultimately kept the future of the New Mexican economy foremost in the minds of the Church and potential renters alike. Finally, changes in administrative or bureaucratic procedures arising from the late colonial Bourbon state cannot account for the rise in the value of the tithe contracts in New Mexico. On this basis, one may argue that the observable increase in the estimated real value of the tithe rental, shown in Figure 3, bore a direct relationship to the production of agricultural goods and livestock by the Vecino population. The tithe rentals, then, suggest that the populace subject to the tithe began to harvest increasing quantities of goods beginning in the 1790 s to roughly the end of the colonial period.

FIGURE 3: ESTIM ATED REAL VALUE OF TITHE RENTAL, NEW MEXICO 1760-1820

(logarithmic scale and peso value)

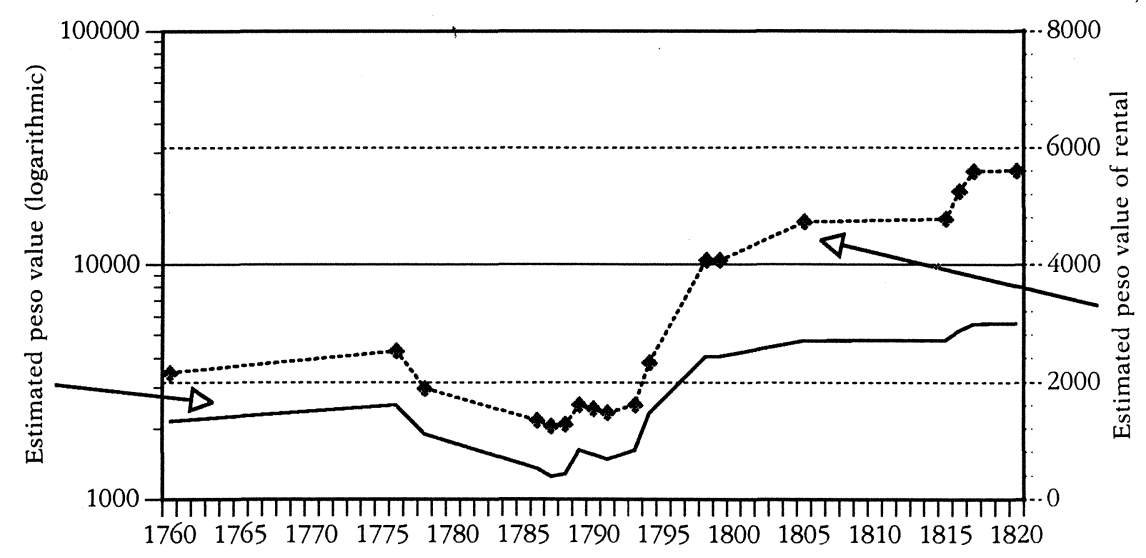

The increase in the real value of the tithe contracts represents a measurable and significant increase in the per capita production of the Vecino population of late colonial New Mexico. The rising real value of the tithe rental signifies an active and expanding provincial economy during the last decades of colonial New Mexico. Figure 4 shows the change in the Pueblo 
FIGURE 4: NEW MEXICO POPULATION SUM MARY, 1731-1821
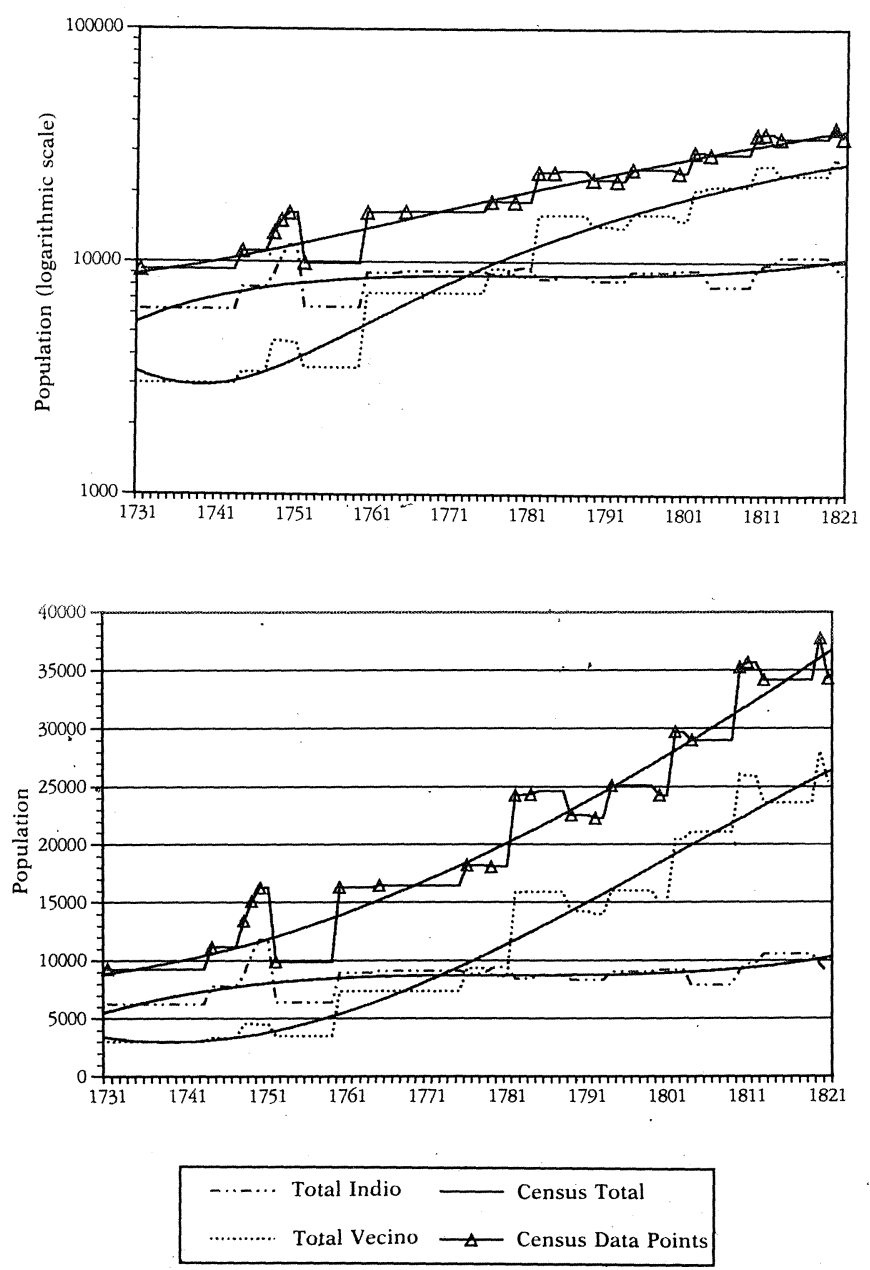

and Vecino population from the estimates of Bishop of Durango Benito Crespo in 1730 to the last Spanish colonial census of 1821 ordered by Governor Facundo Melgares (36). Broadly

(36) The chart was compiled from thirty-two census documents in archives and published sources. Limitations on space prevents a full listing here. A 
speaking, the Vecino population underwent relatively constant expansion throughout the period. It permanently surpassed the Pueblo Indian population by 1780 . The Vecino growth rate from 1784 to 1820 averaged 2.1 percent annually, in contrast to the 1750-1784 period which saw a 7.4 percent average annual growth in population, over three times the later rate.

Since the Vecino population determined the shape of demographic change, and the Church assessed the tithe on only the non-Indian population in New Mexico, one can examine the relationship between Vecino population and the value of tithe rentals during the'critical period between 1760 and 1820. Figure 5 plots the Vecino population for these six decades from the censuses listed in Table 1. It also shows the estimated real value of the tithe rental obtained by dividing the original rental series (Table 1, column 2) by the adjusted price index (Table 1, column 7). The tithe rental series resulting after the adjustment for inflation, although fragmentary, suggests an impressive increase in real value compared to the growth in the Vecino population that paid the tithe.

Figure 5 shows the growth of the Vecino population and the estimated value of the tithe rental for the purpose of comparison. Looking at Figure 5, one can intuitively separate the line representing the estimated value of the tithe rentals into two distinct slopes, intersecting sometime in the 1780s. The Spanish-Comanche peace and alliance concluded in 1785, and the official reports indicating the quickening of long-distance trade from New Mexico south to Chihuahua beginning around the same time, suggest the mid-1780s as the point where the rate of real growth in tithe rental value departed from the rate of increase among the Vecino population. Accordingly, Figure 6 depicts the different slope of the estimated value of the tithe ren-

\footnotetext{
comparison with the tables in Ramón GutiérRez, When Padre Jesús Came, the Corn Mother Went Away: Marriage, Sexuality, and Power in New Mexico, 1500-1846, Stanford: Stanford University Press, 1991, pp. 166-175, will find similar general conclusions about eighteenth and early nineteenth century demography. My interpretation of the figures from each census is explained in FRANK [25], Table 1 and Sources and Notes for Table 1: Colonial New Mexico Censuses, 1706-1821.
} 
FIGURE 5: VECINO POPULATION RELATIVE TO ESTIMATED REAL VALUE OF TITHE RENTALS, NEW MEXICO 1760-1820

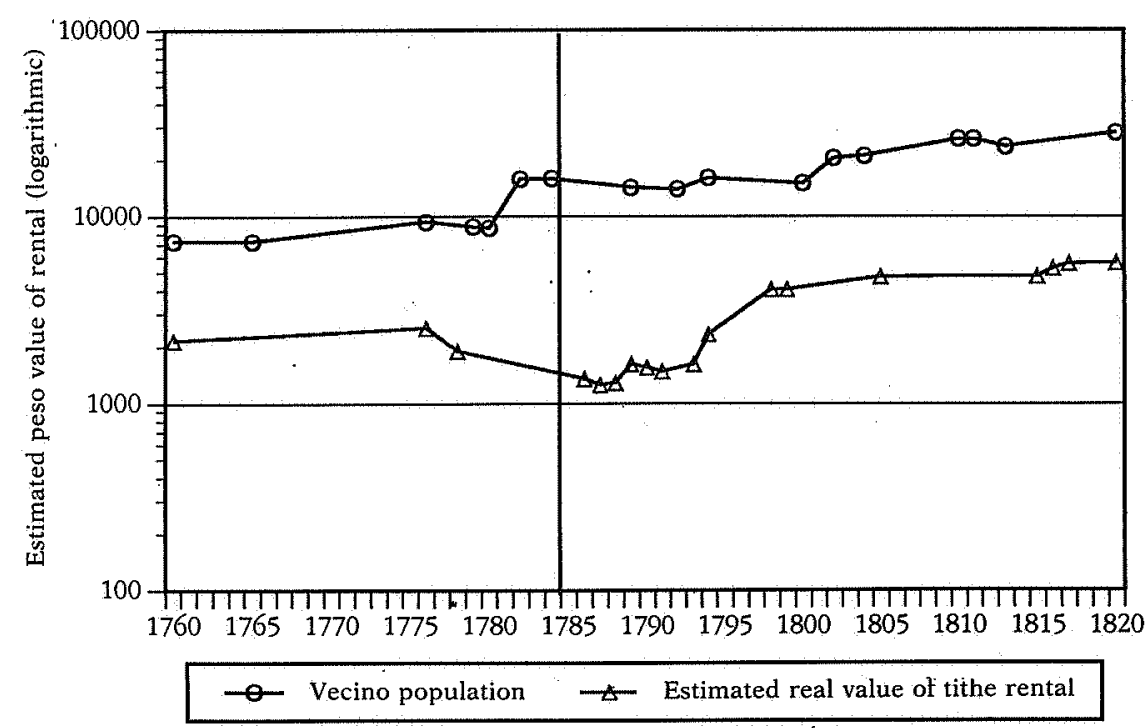

tal series before and after 1785 (37). Slope 2 shows a marked rising trend after 1785 in the real money value of the goods contributed to the tithe. Since the growth suggested in Figure 6 excludes inflation, and the variables affecting the tithe auction and collection did not greatly affect this trend, higher real tithe values reflect an increase in the production of the population that paid the tithe. Put another way, the Vecinos in New Mexico produced more maize, wheat, sheep, and other goods from about 1785 to the end of colonial rule.

Figure 7 plots the relationship between the percent growth of the Vecino population and the tithe rental index (Table 1,

(37) The two fitted curves show the linear regression of the adjusted tithe rental for the purposes of comparison only.

$\begin{array}{lll}\text { Slope } 1(1760-1785): & f(x)=1.362978 E+2^{*} x+-2.289617 E+3 & R^{\wedge} 2=2.345673 E-1 \\ \text { Slope 2 }(1785-1820): & f(x)=8.358863 E+1^{*} x+-1.851909 E+1 & R^{\wedge} 2=6.322623 E-1\end{array}$

R. I., $1996, n^{\circ} 208$ 
FIGURE 6: COMPARISON OF ESTIMATED PESO VALUE OF NEW MEXICAN TITHE RENTAL (ADJUSTED FOR INFLACTION) BEFORE AND AFTER 1785

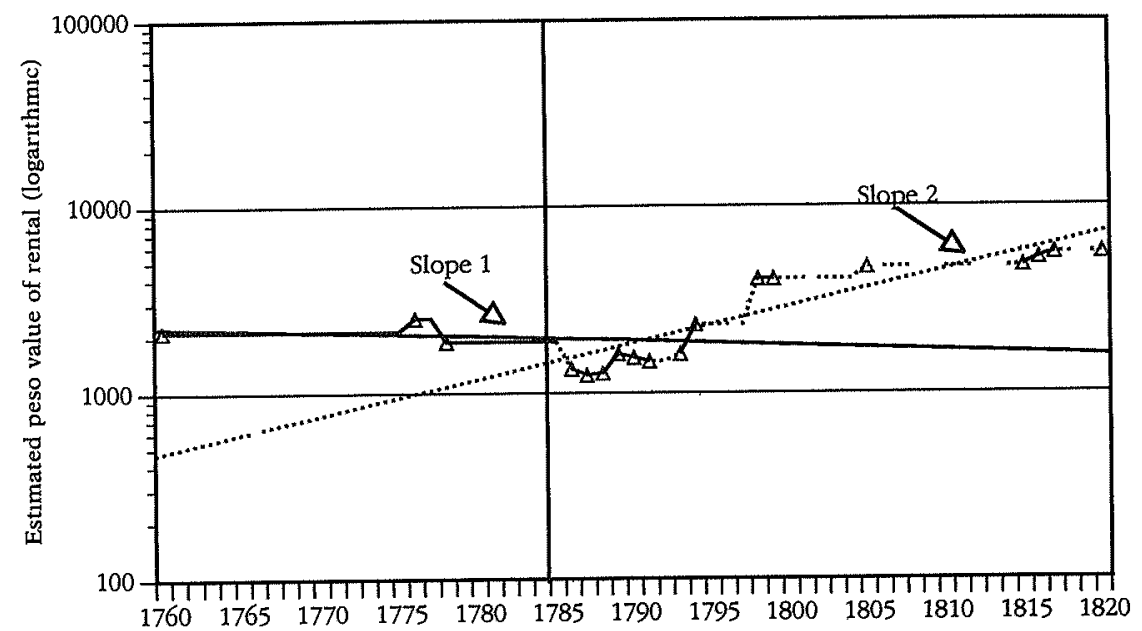

column 8), each from the baseline of 1774-1783 used in Table 1. Between 1760 and 1785, the Vecino population grew more quickly than production (38). Shortly after 1785 , increased output of foodstuffs, other agricultural items, and livestock began to outpace the growth of the New Mexican population. The Vecino population increased at an average annual rate of 2.12 percent from 1785 to 1820 , while the estimated real value of the tithe rental increased at more than double that rate, an average rate of 5.6 percent per year. The percent change of the rental value surpassed the percentage increase in Vecino population somewhere between 1794 and 1798. In the left-hand side of Figure 7 , the added line was derived by dividing the tithe rental

(38) Vecıno population grew at an average rate of 466 percent per year between 1760 and 1785, compared to a decrease of almost one-half percent per year for the value of the tithe rentals Note that the statistic for the tithe rentals from 1760 to 1785 is a based en too few samples $(n=3)$ to be of much statistical value 
by the Vecino population to yield the per capita productivity suggested by the tithe rental data. As only a limited number of sample years produced complete price information necessary for the deflation of the tithe rental (Table 1, columns 4-7), this measure of the change in Vecino per capita production represents only a tentative, but none the less significant, indication of substantial increase in Vecino economic output from the late 1780 s to at least 1815 in New Mexico.

FIGURE 7: PERCENT GROWTH IN VALUE OF TITHE RENTAL

RELATIVE TO VECINO POPULATION, NEW MEXICO 1760-1820 $(1774-1783=100)$
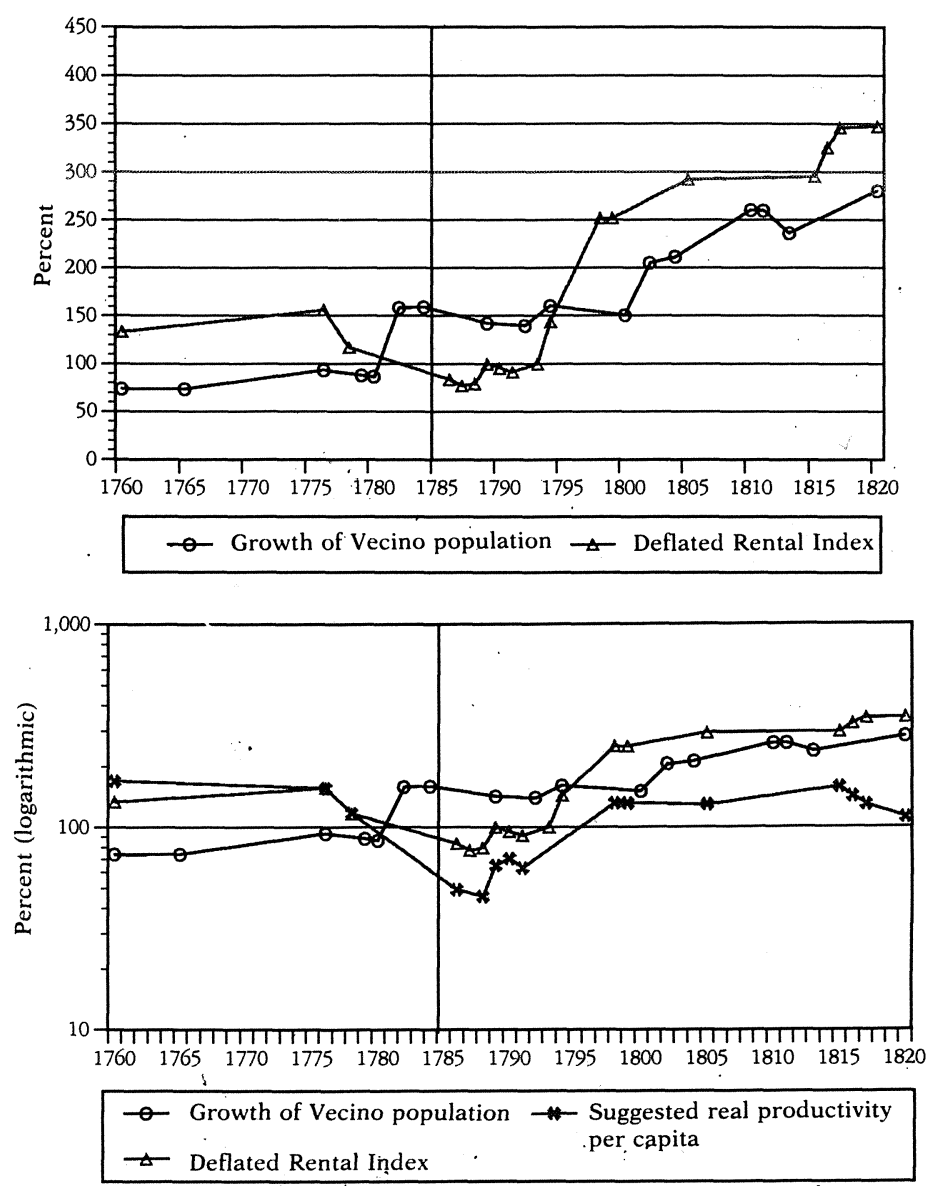

R. I., 1996, n. 208 
The quickening of the New Mexican economy also manifested itself in a change in goods that nuevomexicanos exported to other parts of New Spain. The first eighteenth century longdistance trade system, enduring into the 1770 s, principally supplied deer skins and buffalo hides obtained in trade from the Plains Indians at annual trade fairs at Taos and Pecos pueblos (39). Some blankets and other woven goods went south, as did a small amount of livestock. The quickening of the economy in the 1780s encouraged by rejuvenated long-distance trade brought with it an expansion of the range of export items. The market for New Mexican woolen textiles and finished blankets and clothing expanded along with the population of the urban centers of Nueva Viscaya and the establishment of new presi: dios in the north in the 1770s. Sheep and their by-product, wool, became the mainstays of the late New Mexican colonial economy. Other livestock, grain, punche, and the traditional export of hides rounded out a group of products which, by the 1790s, looked much closer to the produce of other areas of Nueva Viscaya.

After 1780, New Mexican products became far better integrated into to larger economy of Nueva Viscaya. New Mexican textiles and wool show up in the 1780s in records of Chihuahuan merchants, the town council (ayuntamiento), and the municipal textile workshop (obraje) of Chihuahua (40). Frasadas (woolen blankets) from New Mexico appear in the inven-

(39) Proceedings regarding debt owed to the estate of Juan Reaño, Santa Fe, 29 VI-13 VIII 1761, SANM II 9:386-400, TW n.' 559. In lieu of a list of documents, reference to a few of the published documents suffices to describe the trade south: Report of the Father Provincial, Fray Pedro Serrano to the Viceroy, Marquis of Cruillas..., 1761, in Charles W. HACKETT, Historical Documents Relating to New Mexico and Nueva Viscaya, and Approaches Thereto, to 1773. Carnegie Institute Publication, Washington D.C., 1937, 3, pp. 486-487, taken from AGN:HI 25; MORFi [20], p. 133; DOMINGUEZ, [14], pp. 244-245, 254-255, 272, 322-323.

(40) Pagos a soldados a si como los raciones y generos..., 1778, Archivo Palacio Municipal, Chihuahua, (CPM), Hacienda (HA), caja 45, expediencia 6, 4R-95R; CPM:HA, caja 46, 17:8R-10-R; the obraje records appear in CPM:NO (Notaría) 5, caja 46, 7:1R (Haviendo tratado la Junta Municipal... con don Miguez Ortiz vecino de la Villa de Santa Fe de nuevo México), and expediencia 11 (Cuenta de Hacienda y Tesorería del Ayuntamiento de Chihuahua). 
tory of the major house of commerce in Durango (41). The obraje in Chihuahua contrated a year in advance for wool from New Mexico to be delivered in 1794; a huge herd of New Mexican livestock figured promimently in a partnership, entered into in 1795, between Fernando de la Concha, at that time the departing Governor of New Mexico, a prominent Chihuahua merchant, and the administrator of the Hacienda de Encinillas (near Chihuahua), in order to supply the Chihuahua market (42).

The economic and demographic developments which shaped New Mexico during the last decades of Spanish colonial rule directed and deepened social and cultural change. Population and commercial expansión in the province between 1780 and 1820 formed the basis for the generation of a mature and self-confident Vecino society, manifested in the creation of new forms of social behavior, and cultural and religious expression, and which increasingly defined itself in contrast to the Pueblo Indians.

Colonial marriage records indicate a process of selfdefinition taking place within Vecino society. By the 1780s, the male/female ratio among Vecinos had dropped to somewhere around 87 to 94 men per 100 women, the result of losses during the preceding decades of fighting and increased intermarriage with Pueblo Indians and Plains Indians captives (43). Work done by Ramón Gutiérrez using the diligencias matrimoniales, the investigation required by Canon law in order to ensure that no impediments to marriage existed, show that the age difference between spouses decreased significantly at the same time (44). Both phenomena serve as indications that New Mexican Vecinos no longer had the demographic profile of a young frontier society.

(41) Nota de lo que he comprado a don Antonio Ondarza..., Juan José Zambrano, Palacio Gobierno, Durango (DUR:PG) cajón 9, 3:52V.

(42) Contract between don Francisco de Elguea, don Phelipe Gonzales de Cosio, and Coronel don Fernando de la Concha, Registro de Propiedades, Archivo Histórico, Chihuahua, (CHI:RG) libro 34 11R-15R.

(43) Ramón GuTIÉRREZ, [36], p. 281, and census returns of 1789, 1794, 1804, 1810,1811 , and 1821 .

(44) GuTIÉRREZ, [36], pp. 278-281.

R. I., 1996, n. 208 
The demographic evidence also shows a new concern with ethnic divisions of the population during the $1760-1800$ period. Ethnic classifications based on the product of mixed-marriages appear in the New Mexican documents from the early years of the province, but their usage underwent a marked change towards the end of the eighteenth century. After 1760, the ethnic designations of respondents appear in increasing number in the records of the diligencias matrimoniales. In addition, the investigating friar included consistently for the first time in his report some ethnic labels denoting the offspring of mixed-marriages, such as Color Quebrado, Coyote, and Mulato (45). This change reflects two trends: the increasing frequency of endogamous, cross-ethnic marriages encouraged by a quarter century of close proximity and collaboration due to the Plains Indian threat; and a heightened sensitivity to racial designations, at least on the part of the responsible missionary (46). Gutiérrez, in his investigation of the diligencias matrimoniales, divided the marriage population into Vecinos, Indios, and Castas and tested the association of bride and groom's racial designation against a model assuming the random selection of a mate (47). He found that the partners of marriages represented in his sample expressed a marked preference for a spouse from their own racial category through the $1760 \mathrm{~s}$. This association decreased dramatically through the 1770 s and into the 1780 s when spouses appear to marry with little regard for the ethnic status. Beginning around 1790 the trend reverses, until in the early 1800 s the statistic used for demonstrating marriage preference appears to show that virtually all couples shared the same status, indicated by a perfect association between the bride and groom's ethnicity.

Two changes of great significance to the understanding of late colonial society underlie the ending of the period of increased intermarriage. Additional analysis of the information tabu-

(45) Ibidem, pp. 284-285, and see 289.

(46) Concerning the closer cooperation between Vecinos and Indios during the 1760-1780 period, see Oakah L. JoNES Jr., "Pueblo Indian Auxiliaries in New Mexico, 1763-1821», New Mexico Historical Review, 37:2, 1962, pp. 81-111; and Okah L. JONES, Jr., Pueblo Warriors and Spanish Conques, Norman, 1966.

(47) GUTIÉRREZ [36], pp. 287-292. 
lated by Gutiérrez indicates that Vecinos did choose fewer Pueblos Indians in marriage after the 1780 s. Figure 8 represents the percentage of the marriages investigated by the Church that took place between a Vecino and Pueblo Indian, displayed by decade. As the friars undertook diligencias matrimoniales whenever Indians married outside their Pueblo, Figure 8 indicates a substantial drop in inter-ethnic marriages taking place coincident to the period of rapid growth in Vecino economic activity.

FIGURE 8: VECINO-INDIO MARRIAGES A AS PERCENTAGE OF ALLL MARRIAGES REPRESENTED IN DILIGENCIAS

MATRIMONIALES, NEW MEXICO, 1700-1839
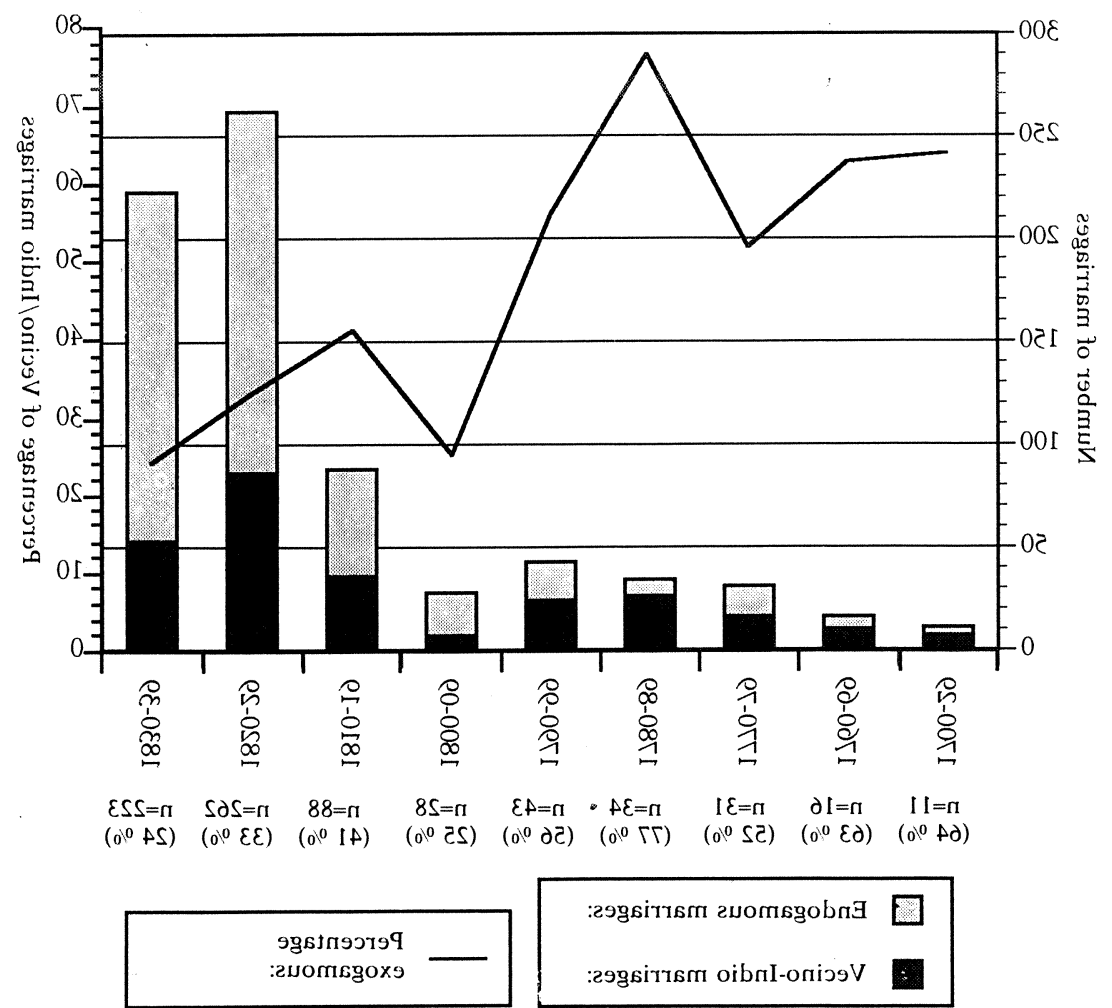

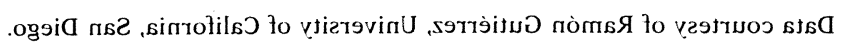

R. I., 1996, n.० 208 
At the same time, the proliferation of ethnic classifications found in the diligencias starting in the 1760s had virtually disappeared by the end of the eighteenth century. Similarly, many census documents which had counted Vecinos, Indios, and Castas in the 1760s through 1780s listed only two classifications, Indios, and Vecinos y Castas, or just Vecinos (or Españoles), later in the century (48). The mixed-race classifications in use in New Mexico became incorporated into the Vecino label as a grouping by cultural affinity. The collapsing of the terms describing mixed-race peoples into one non-Indian group left a bipolar system that resembles the early eighteenth-century distinction between Vecino and Naturale, except that while the old terms. represented different ethnic groups, the new ones signified a distinction in cultural terms. "Vecino", or "Español», now encompassed hispanicized Genizaros and Castas. Labeling groups by a set of primarily cultural instead of ethnic characteristics underscores the significance of this period in the self-definition of frontier society in New Mexico. After three decades of cooperation and intermarriage between Pueblo Indians and their neighbors, Vecinos at the end of the eighteenth century had begun to fashion their own cultural identity defined in part in contradistinction to the Pueblos.

The connection between the economic boom at the end of the eighteenth century and the assertion of the emerging Vecino cultural identity manifested itself in the aggressive manner in which Vecinos began to usurp and limit the economic function of the Pueblos after 1780. In response to the reopening of the Chihuahua trade after the Indian wars of the 1760s and 1770s, Vecinos in New Mexico intensified their own production of goods, taking over areas of production in which the Pueblo Indians had previously dominated, and attempting to take Indian lands and extract goods services from the pueblos.

A look at the production of textiles in New Mexico provides a case in point. The materials relating to the New Mexican trade with Chihuahua make clear that before the period of Plains

(48) Ibidem, p. 288, and the observation of Horvath, Genizaros, 96-102, that the 1790 census takers were far more rigorous in their identification of people as Castas or Genizaros than were most of the contemporary missionaries. 
Indian incursion, the Pueblo Indians participated directly in the long-distance trade, taking cotton mantas and other goods south in the annual convoy (49). Beginning with the economic resurgence of the 1780s, Vecino middlemen brought Indian goods south, traded imported materials into the Pueblos, and reaped a large profit (50). This pattern also applied increasingly to Vecinos who did not have access to credit or capital towards the end of the eighteenth-century.

The end of the direct marketing of Indian goods appears most visibly in the sudden development and extension of Vecino weaving, named the Río Grande Blanket style, which became established in the early 1780s, and replaced pueblo-made cotton and woolen mantas as items for the export market (51). Vecino crafts people wove Río Grande blankets on a narrow Spanish-style treadle loom, instead of the wider Indian vertical loom, and used decorative elements closer to those used in other parts of New Spain than to the designs on contemporary pueblo-woven textiles (52), Indian textiles produced in the traditional manner, particularly cotton materials, became restricted to utilitarian and ceremonial clothing for use inside the pueblo.

The growth in the Vecino population towards the end of the eighteenth century, coupled with the need for land with which to increase agricultural production, gave rise to a sustained effort to add to the amount of land under Vecino cultivation.

(49) Nicolás DE LA FoRA, The Frontiers of New Spain, Ed. Lawrence Kinnaird, The Quivira Society, Berkeley, 1958, pp. 94-95.

(50) MoRfi, Geographical Description, 14; Marc SImmons, "The Chacón Economic Report of 1803", New Mexico Historical Review, 60:1 (1985), p. 87. Republished as Fernandio DE CHACÓN, «Report of Governor Chacón, 1803», Coronado's Land: Essays on Daily Life in Colonial New Mexico, Ed. Marc Simmons. Albuquerque: University of New Mexico Press, 1991, p. 170.

(51) Simmons [50], pp. 84-86; Ward Alan MingE, «Efectos del País: A History of Weaving along the Río Grande», Spanish Textile Tradition of New Mexico and Colorado, Nora FISHER, ed. Santa Fe, 1979, pp. 15-22; and Dorothy Boyd BowEN, "A Brief History of Spanish Textile Production in the Southwest", in FISHER, Spanish Textile Tradition, p. 6.

(52) An example would be the New Mexican textiles with designs apparently based upon Saltillo blankets. See James JETER and Paula Marie JUELKE, The Saltillo Sarape, Santa Barbara, 1978, pp. 24-25. 
Territorial expansion radiating from existing settlements occurred in practically all parts of the province beginning in the 1780 s, shortly after the defeat of Cuerno Verde (53). Vecinos resettled lands that had been abandoned during the Plains Indian hostilities and opened new areas to settlement. In the 1790s, for example, New villages began to form along the Río Colorado, northwest of Santa Cruz de la Cañada, and move up the Chama valley (54). North of Taos, Vecino groups received grants of land for new villages along tributaries of the Río Grande, establishing Arroyo Hondo, Arroyo Seco, Valdez, and Des Montes in close succession after 1810 (55). The Mora valley to the west of Taos also saw new settlements established starting in the 1790s (56). The geographical expansion of Vecinos from the Río Grande valley at turn of the nineteenth century formed the beginning of the process that Nostrand described using the 1850 and 1900 census returns (57).

Population growth and increased economic activity in New Mexico provided the impetus for the self-definition of a Vecino

(53) Three examples: Chama valley, see Frances Leon SwADESH, Los Primeros Pobladores, Notre Dame, 1974, pp. 48-51; Taos valley: see Myra Ellen JENKINS, "Taos Pueblo and its Neighbors", New Mexico Historical Review, 41:2, 1966, pp. 99-104, and John O. BAXTER, Spanish Irrigation in Taos Valley, Santa Fe: New. Mexico State Engineer Office, 1990; Pecos: G. Emlen HALL, Four Leagues of Pecos: A Legal History of the Pecos Grant, 1800-1933. Albuquerque, 1984, pp. 4-30. Expansion in the rest of the province can be gauged by the discussion in Richard L. Nostrand, "The Century of Hispano Expansion", New Mexico Historical Review 64:4, 1987, p. 361-386. Much if the content of this article and the Nostrand's larger arguments is restated in The Hispano Homeland. Norman: University of Oklahoma Press, 1992.

(54) SWADESH [53], 1974, pp. 47-52.

(55) JENKINS [53], 361-366.

(56) Fray Angelico CHAvez, "Early Settlements in the Mora Valley», El Palacio, 62:11, 1955, pp. 318-324. As these examples indicate, geographic expansion favored Rio Arriba, the portion of the province north from Santa Fe. The percentage of the province's population living in Río Arriba grew from forty-nine in 1789 , to well over fifty-six percent in 1821. The years for which tithe receipts by district survive, show that the bulk of the agricultural production came from the northern part of the province, although during this period the Rio Abajo came to dominante the raising of sheep.

(57) See Richard L. NoSTRAND, "Mexican Americans Circa 1850", Annals of the Association of American Geographers, 65, 1975, pp. 378-390, as well NosTRAND [1] and Nostrand [53]. 
social identity. This, in turn, gave rise to new areas and forms in which Vecino society expressed itself culturally. A Vecino religious movement emerged at the end of the eighteenth century, characterized by artisan-made religious images, santos, and the lay organization Los Hermanos Penitentes. Vecino craftsmen began producing images of saints for the missions, chapels, and churches around 1790 . In addition to creating a distinctive folk style, the santeros translated traditional religious personages and scenes into the context of the New Mexican late colonial experience. The secular brotherhood of Penitentes also emerged in New Mexico during the last decades of the Spanish period. The Penitente emphasis on the suffering and redemption of Christ, taken to the extent of elaborate rituals of flagellation and the reenactment of the Passion, represented a popular religious movement whose spiritualism and iconography exemplified the articulation of a powerful, self-confident, Vecino worldview emerging from the changes and ordeals of the preceding half-century. The flowering of religious folk-art, and the growth of the Penitente organization, both directly reflected patronage made possible by increased late colonial economic activity.

So too did the Vecino traditions of furniture craftsmanship and decoration, folk-plays, folk-songs -in fact almost all of the aspects of Hispano culture over which Nostrand and his critics contended- and these cultural traits also emerged out of the rich Vecino soil of late colonial New Mexico. The economic developments during the late colonial period, in particular, the spurt of long-distance trade which sparked an economic boom in New Mexico, played a determining role in the creation of a Vecino culture in New Mexico, based on an experience and a derived world-view distinct from other areas of contemporary New Spain. It is this period, not that of Onate's conquest and colonization of the province in the sixteenth century, and not the reconquest of de Vargas in the 1690s, that provides the historical underpinning for the cultural assumptions on which Richard Nostrand based his «Hispano Homeland» thesis.

From the perspective of the tremendous changes that took place in the cultural and economic fabric of late colonial New Mexico, the original rounds of the Hispano Homeland debate seem curiously disconnected from their proper historical foundation. Nostrand's focus on the connection between Spain and

R. I., 1996, n.o 208 
the settlers of New Mexico collapses the process of change over time and leaves his central argument concerning the geographical expansion of «Hispanos» hanging by a thread woven of historical myth. New Mexicans did not come «more directly from Spain", nor do whatever "archaic Iberian cultural attributes that have been preserved» have much to do with what Nostrand finds in the census returns at the turn of the twentieth century (58). The critiques of Nostrand's formulation joined the debate over distinctiveness at this vulnerable juncture, the problem of connecting the census returns to a historically discernible group of people. Blaut and Ríos-Bustamante argue that "no such place exists» as the «uniquely Spanish, nonMexican culture in New Mexico" described by Nostrand (59). They accuse Nostrand of replacing a common Mexico culture and community with separate subcultures, and in so doing conforming with a traditional «thought style» that promotes the Anglo-American interest in breaking up Latino political, social, or economic solidarity.

The irony here cuts both ways. Both the dynamic vitality of Vecino culture, radiating outward geographically from the Río Grande Valley, and many of the distinctive cultural elements that Nostrand discusses, proceeded directly from an era of Vecino economic activity and related cultural fluorescence in New Mexico at the end of the eighteenth century, not simply from being "distinctively Spanish in a cultural sense» (60). Within this region, located on the northernmost frontier of New Spain, Vecinos formed the basis for their own unique, articulation of Spanish colonial culture and community, the very substance that Blaut and Ríos-Bustamante found wanting in Nostrand's argument. The cultural roots of New Mexican Vecinos did not differ markedly in this respect from of Californios, Tejanos, Filipinos, or other Spanish settlers at similar points in their regional adaptations, but the historical developments that the last generation of Vecinos under Spanish rule

(58) Nostrand [1], p. 382; and Nostrand, [4], p. 283.

(59) Blaut and Rios-Bustamante [3], p. 157 and 159.

(60) Richard L. Nostrand, "Hispano Cultural Distinctiveness: A Reply", Annals of the Association of American Geographers, 74:1, 1984, p. 164. 
experienced and helped to fashion profoundly affected the demographic growth, geographic range, and cultural cohesiveness of their offspring. For too long, the debate over the distinctiveness of Hispanic New Mexican culture has missed the origin of the cultural forest for a fascination with the surviving trees.

La mayor parte de la historiografía sobre Nuevo México asume que esta región es culturalmente distinta al resto, aunque se haya perdido la verdadera fuente histórica de su unidad. Este ensayo argumenta que los "nuevomexicanos» emergieron en el periodo colonial tardio de Nuevo Mexico, desde 1786 hasta el estallido de violencia en México en 1810, como un grupo distinto de Vecinos gracias a la expansión del mercado a larga distancia. La dinámica vital de la cultura del vecino y algunos de sus elementos más distintivos proceden directamente de la era de actividad económica en Nuevo México hacia finales del siglo XVIII. 